\title{
Penampilan Pertumbuhan dan Hasil Beberapa Genotipe Jagung Calon Hibrida Umur Genjah di Lahan Kering
}

\author{
Growth and Yield Performance of Candidates Hybrid \\ Maize Genotypes for Early Harvest Trait in Dry Land
}

\author{
St. Subaedah", Sudirman Numba, dan Saida \\ ${ }^{1}$ Jurusan Agroteknologi, Fakultas Pertanian, Universitas Muslim Indonesia, Makassar \\ J1. Urip Sumoharjo KM 05, Makassar, Indonesia
}

Diterima 2 Agustus 2017/Disetujui 29 Juni 2018

\begin{abstract}
Maize is commonly developed in dry land areas with limited irrigation water in Indonesia, thereby posing a threat to its poductivity. Thus, availability of early harvest varieties able to adapt to limited water is important. The aim of this study was to analyze the performance of maize hybrid genotypes candidates in dry land. The research was conducted from April to July 2016 at Gowa, South Sulawesi. The experiment was designed with a randomized complete block design consisting of 8 genotypes, namely GJ1, GJ2, GJ3, GJ4, GJ5, GJ6, GJ7, GJ8, and two control varieties, i.e., Bima 7 and Lamuru. The results showed genotypes GJ1, GJ6, GJ7 and GJ8 had higher plant growth as compared to Bima 7 and Lamuru. All genotypes were harvested less than 90 days. Genotypes GJ6, GJ7, and GJ8 yielded 6.85 tons ha ${ }^{-1}, 6.51$ tons ha and $^{-1} .31$ tons $\mathrm{ha}^{-1}$, respectively, which were higher $13-45 \%$ than the Lamuru control variety. Because this experiment was carried out in an optimun condition, it would be necessary to further study the three genotypes in drought stress conditions before being developed for early harvest and high yielding hybrid varieties.
\end{abstract}

Keywords: early harvest, genotype, maize, performance

\section{ABSTRAK}

Tanaman jagung umumnya ditanam di lahan kering yang sumber airnya sangat terbatas, sehingga menyebabkan produksinya rendah. Maka, perlu dikembangkan varietas jagung hibrida umur genjah yang dapat beradaptasi terhadap ketersediaan air yang terbatas. Penelitian ini dilakukan dengan tujuan untuk menganalisis keragaan genotipe-genotipe jagung calon hibrida umur genjah di lahan kering. Penelitian berlangsung dari April sampai Juli 2016 di Kabupaten Gowa, Sulawesi Selatan. Penelitian dirancang dengan rancangan acak kelompok (randomized complete block design) yang terdiri atas 8 genotipe yaitu GJ1, GJ2, GJ3, GJ4, GJ5, GJ6, GJ7, GJ8 dan dua varietas pembanding yaitu Bima 7 dan Lamuru. Hasil penelitian menunjukkan bahwa genotipe GJ1, GJ6, GJ7, dan GJ8 memperlihatkan pertumbuhan tanaman yang lebih tinggi dibandingkan dengan varietas pembanding Bima 7 dan Lamuru. Genotipe-genotipe yang diuji mempunyai umur panen kurang lebih 90 hari. Genotipe GJ6, GJ7, dan GJ8 berturut-turut menghasilkan 6.85 ton ha-1, 6.51 ton ha dan $^{-1} .31$ ton ha', yang lebih tinggi 13-45\% dibandingkan dengan varietas pembanding Lamuru. Oleh karena penelitian ini dilakukan pada kondisi optimum, maka perlu kajian lebih lanjut terhadap ketiga genotipe tersebut pada kondisi cekaman kekeringan di lapangan sebelum dikembangkan untuk menghasilkan varietas hibrida jagung umur genjah dan berproduksi tinggi.

Kata kunci: genotipe, keragaan, tanaman jagung, umur genjah

\section{PENDAHULUAN}

Permintaanjagung dari tahun ke tahun makin meningkat dan hal ini juga dipicu oleh karena negara penghasil jagung seperti Amerika, Argentina dan China mengembangkan industri bioetanol (Utomo, 2012). Pemanfaatan jagung yang

\footnotetext{
* Penulis untuk korespondensi. e-mail: st.subaedah@umi.ac.id
}

semula untuk bahan makanan dan pangan, kini telah berubah menjadi komoditas industri (Iriany et al., 2011; Prabowo et al., 2014). Mengingat sebagaian pasokan jagung Indonesia bersal dari impor (BPS, 2016), maka peningkatan produksi dalam negeri perlu terus diupayakan.

Peningkatan produksi dapat dilakukan melalui perluasan areal maupun penggunaan benih unggul, disertai dengan penerapan teknologi budidaya. Jagung hibrida menjadi pilihan karena mampu berproduksil lebih tinggi 
karena memiliki gen-gen dominan (Putra et al., 2008; Ali et al., 2012), lebih tahan terhadap hama dan penyakit, lebih tanggap terhadap pemupukan, produksi lebih seragam, dan bobot biji lebih berat (Puslitbangtan, 2007). Namun demikian varietas jagung hibrida yang ada umumnya memiliki umur panen lebih dari 90 hari.

Pengembangan varietas unggul jagung umur genjah (80-90 hari) dan super genjah (70-80 hari) merupakan salah satu upaya untuk meminimalisasi kegagalan panen akibat pendeknya periode hujan (Azrai, 2013). Penurunan produksi akibat kekeringan dapat mencapai 30-40\% (Subaedah et al., 2014). Tanaman jagung berumur genjah sangat diperlukan petani terutama pada lahan tegal yang sering mengalami kekeringan pada fase pengisian biji (Azrai, 2013). Kekeringan pada fase ini mengakibatkan pembentukan biji yang tidak optimal atau bahkan sama sekali tidak ada biji yang terbentuk karena adanya reduksi hasil fotosintesis (Chaves et al., 2009; Epeoglu, et al., 2009; Subaedah, et al., 2014; Subaedah, et al., 2016). Perubahan lainnya yang akan berpengaruh terhadap kegiatan budidaya tanaman adalah pergeseran distribusi hujan yang semakin sulit diprediksi sehingga penentuan waktu tanaman sulit dilakukan dan kegagalan panen semakin besar (Balitbang Pertanian, 2011). Penelitian ini dilakukan dengan tujuan untuk menganalisis keragaan beberapa genotipe jagung calon hibrida umur genjah di lahan kering.

\section{BAHAN DAN METODE}

Penelitian ini dilaksanakan di lahan kering Kebun Percobaan Balitsereal Kabupaten Gowa Sulawesi Selatan, dengan jenis tanah Ultisol dan tipe iklim C3, yang berlangsung dari bulan April sampai Juli 2016. Benih diperoleh dari Balitsereal terdiri dari 8 genotipe (GJ1, GJ2, GJ3, GJ4, GJ5, GJ6, GJ7 dan GJ8) dan dua varietas pembanding (Bima 7 dan Lamuru). Populasi dasar berasal dari CIMMYT Mexico dari persilangan kelompok umur genjah dan toleran kekeringan. Penelitian dilakukan dengan rancangan acak kelompok yang terdiri dari sepuluh perlakuan genotipe dan diulang tiga kali sehingga diperoleh 30 unit percobaan.

Lahan penelitian dibajak kemudian digaru untuk menghancurkan bongkahan tanah dan selanjutnya dirotari. Setiap unit percobaan berukuran $5 \mathrm{~m} \mathrm{x} 3 \mathrm{~m}$ dan jarak antara unit $1.5 \mathrm{~m}$. Penanaman dilakukan pada tanggal 13 April 2016. Benih ditugal dengan jarak tanam $70 \mathrm{~cm} \mathrm{x} 20 \mathrm{~cm}$ dengan 2 benih per lubang.

Pupuk kandang diberikan bersamaan dengan pengolahan tanah sebanyak 20 ton ha $^{-1}$. Selama pemeliharaan diaplikasikan Furadan $3 \mathrm{G}$ dengan dosis 8-10 kg ha-1. Pemupukan pertama dilakukan pada 7 hari setelah tanam dengan pemberian NPK Phonska 15:15:15 dengan dosis $350 \mathrm{~kg} \mathrm{ha}^{-1}$ ditambah dengan Urea $150 \mathrm{~kg} \mathrm{ha}^{-1}$. Pemupukan kedua dilakukan pada umur 30 hari setelah tanam yaitu pemberian Urea dengan dosis $250 \mathrm{~kg} \mathrm{ha}^{-1}$ dan NPK Phonska 15:15:15 dengan dosis $100 \mathrm{~kg} \mathrm{ha}^{-1}$, sedangkan pemupukan ketiga diberikan pada umur 45-50 hari setelah tanam dengan dosis $150 \mathrm{~kg}$ urea ha- ${ }^{-1}$ Penyiangan dilakukan 2 kali yaitu pada waktu tanaman berumur 3 dan 6 minggu setelah tanam (MST). Penyiangan kedua dilakukan bersamaan dengan pembumbunan. Pengairan dilakukan setiap 10 hari dengan mengalirkan air ke dalam petakan-petakan percobaan. Panen dilakukan pada saat biji masak fisiologis ditandai terbentuknya black layer.

Peubah yang diamati dan diukur dalam penelitian ini meliputi tinggi tanaman, jumlah daun, luas daun, umur $50 \%$ berbunga jantan, umur $50 \%$ berbunga betina, anthesis silking interval (ASI) yaitu selisih hari antara keluarnya serbuk sari dengan keluarnya rambut, tinggi tongkol, dan umur panen. Peubah lain adalah komponen hasil yang meliputi bobot tongkol, bobot tongkol per petak dan bobot biji kering (kadar air 15\%) per hektar dengan rumus:

$$
\text { Hasil }\left(\text { ton } \mathrm{ha}^{-1}\right)=\frac{10000}{\text { L.P }} \times \frac{100-\mathrm{KA}}{100-15} \times \mathrm{B} \times 0.80
$$

(Firdaus, et al., 2002).

K.A = Kadar air biji waktu panen

L.P $=$ Luas petak $\left(\mathrm{m}^{2}\right)$

$15=$ Kadar air biji $15 \%$

$\mathrm{B}=$ Bobot tongkol kupasan per petak $(\mathrm{kg})$

0.80 = Rata-rata "shelling percentage (rendemen)"

\section{HASIL DAN PEMBAHASAN}

\section{Tinggi Tanaman, Jumlah Daun dan Luas daun}

Tinggi tanaman jagung dan jumlah daun pada umur 8 MST dipengaruhi oleh genotipe. Genotipe GJ1, GJ3, GJ4, GJ6, GJ7, dan GJ8 lebih tinggi(230.60-240 cm) dibandingkan dengan kedua varietas pembanding yang digunakan (Bima 7 dan Lamuru) yang memiliki tinggi tanaman sebesar 212.67-213.44 cm (Tabel 1). Hal ini menunjukkan bahwa perbedaan genotipe tanaman memperlihatkan perbedaan pertumbuhan tanaman. Hasil penelitian ini sejalan dengan penelitian yang dilakukan oleh Suwarno et al. (2016) yang menunjukkan bahwa genotipe berpengaruh nyata terhadap karakter panjang daun bendera dan tinggi tanaman padi. Pada peubah jumlah daun, genotipe GJ6 mempunyai daun yang lebih banyak dibandingkan dengan varietas Bima 7 tetapi tidak berbeda nyata dengan varietas Lamuru. Pertumbuhan tanaman yang tinggi mempunyai kemungkinan berdaun lebih banyak. Dengan adanya daun yang lebih banyak memungkinkan penangkapan energi matahari lebih besar yang akan memacu proses fotosintesis lebih pesat dan pada akhirnya akan menghasilkan tanaman dengan pertumbuhan dan produksi yang lebih tinggi.

\section{Umur 50\% Berbunga Jantan, 50\% Berbunga Betina dan} ASI

Hasil pengamatan terhadap waktu munculnya bunga jantan 50\% menunjukkan tidak adanya perbedaan yang nyata dari beberapa genotipe yang diuji. Peubah waktu munculnya bunga betina $50 \%$ menunjukkan bahwa perbedaan genotipe 
Tabel 1. Tinggi tanaman, jumlah daun, dan luas daun tanaman jagung pada umur 8 MST dari berbagai genotipe jagung umur genjah

\begin{tabular}{lclc}
\hline Genotipe jagung & Tinggi tanaman $(\mathrm{cm})$ & Jumlah daun & Luas daun $\left(\mathrm{cm}^{2}\right)$ \\
\hline GJ1 & $240.0 \pm 13.45 \mathrm{ab}$ & $13.2 \pm 0.8 \mathrm{~ns}$ & $1,173.9 \pm 135.01$ \\
GJ2 & $195.1 \pm 8.20 \mathrm{ab}$ & $13.6 \pm 0.9 \mathrm{~ns}$ & $1,088.8 \pm 96.93$ \\
GJ3 & $237.0 \pm 3.46 \mathrm{ab}$ & $13.3 \pm 0.1 \mathrm{~ns}$ & $1,142.2 \pm 46.02$ \\
GJ4 & $230.6 \pm 5.89 \mathrm{a}$ & $14.1 \pm 0.2 \mathrm{~ns}$ & $1,104.3 \pm 14.48$ \\
GJ5 & $206.0 \pm 14.80$ & $13.0 \pm 0.4 \mathrm{~b}$ & $1,005.9 \pm 86.13$ \\
GJ6 & $240.0 \pm 20.22 \mathrm{ab}$ & $15.0 \pm 0.2 \mathrm{a}$ & $1,096.5 \pm 62.35$ \\
GJ7 & $235.1 \pm 18.32 \mathrm{ab}$ & $14.4 \pm 0.2 \mathrm{~ns}$ & $1,090.6 \pm 120.95$ \\
GJ8 & $240.0 \pm 6.01 \mathrm{ab}$ & $14.1 \pm 0.7 \mathrm{~ns}$ & $1,048.2 \pm 79.51$ \\
Bima 7 & $212.7 \pm 4.16$ & $13.2 \pm 0.4$ & $960.2 \pm 111.82$ \\
Lamuru & $214.3 \pm 8.62$ & $14.3 \pm 1.1$ & $1,096.4 \pm 70.50$ \\
\hline NP t-Dunnet $\alpha 0.05$ & 16.53 & 1.27 & $\mathrm{~ns}$ \\
\hline
\end{tabular}

Keterangan: Angka yang diikuti oleh huruf kecil pada kolom yang sama berarti a : berbeda nyata dengan var. Bima 7 ; b : berbeda nyata dengan var. Lamuru berdasarkan Uji t-Dunnet $\alpha 0.05 ; \underline{\mathrm{SD}}$; ns : tidak berbeda nyata dengan kedua varietas pembanding

menyebabkan perbedaan waktu mekarnya bunga betina $50 \%$ (Tabel 2).

Setiap genotipe memiliki lama pertumbuhan vegetatif yang berbeda-beda, sehingga waktu berbunga juga berbeda. Dari beberapa genotipe yang diuji terlihat bahwa GJ4 dan GJ5 memiliki waktu berbunga betina yang tercepat yaitu 47.67 dan 48.33 hari (Tabel 2). Hal ini sesuai dengan hasil penelitian Garba dan Namo (2013) yang meneliti pertumbuhan dan produksi beberapa varietas jagung dan menyimpulkan bahwa pertumbuhan jagung berumur dalam lebih tinggi, namun jagung berumur genjah lebih cepat berbunga. Demikian pula hasil penelitian Bello et al. (2012) yang mengevaluasi varietas jagung berumur dalam, sedang, dan genjah pada kondisi curah hujan yang optimal dan mengemukakan bahwa varietas berumur dalam dan sedang masing-masing memberikan hasil yang lebih tinggi $34.29 \%$ dan $17 \%$ dibandingkan dengan varietas berumur genjah; namun demikian varietas berumur genjah lebih cepat berbunga, sehingga memungkinkan untuk dikembangkan di daerah yang mengalami stress kekeringan yang berkepanjangan. Pemuliaan tanaman bertujuan untuk memperbaiki karakter tanaman sesuai dengan kebutuhan manusia dengan memanfaatkan potensi genetik dan interaksi genotipe dengan lingkungan.

Tabel 2. Waktu muncul bunga jantan 50\%, waktu munculnya bunga betina 50\%, dan ASI dari berbagai genotipe jagung umur genjah

\begin{tabular}{lccc}
\hline Genotipe jagung & Waktu muncul bunga jantan & Waktu muncul bunga betina & ASI (hari) \\
\hline GJ1 & $50 \%$ (hari) & $50 \%$ (hari) & $2.0 \pm 0.0 \mathrm{~b}$ \\
GJ2 & $47.0 \pm 2.0$ & $49.0 \pm 2.0 \mathrm{~ns}$ & $2.0 \pm 0.0 \mathrm{~b}$ \\
GJ3 & $48.3 \pm 1.2$ & $50.3 \pm 1.2 \mathrm{~ns}$ & $2.0 \pm 0.6 \mathrm{~b}$ \\
GJ4 & $49.0 \pm 0.0$ & $51.0 \pm 0.0 \mathrm{~b}$ & $1.3 \pm 0.6 \mathrm{a}$ \\
GJ5 & $47.7 \pm 2.3$ & $48.3 \pm 2.1 \mathrm{~ns}$ & $1.3 \pm 0.0 \mathrm{a}$ \\
GJ6 & $46.3 \pm 0.6$ & $47.7 \pm 1.0 \mathrm{~ns}$ & $2.0 \pm 0.0 \mathrm{~b}$ \\
GJ7 & $48.3 \pm 1.2$ & $50.3 \pm 1.2 \mathrm{~b}$ & $2.0 \pm 0.0 \mathrm{~b}$ \\
GJ8 & $49.0 \pm 0.0$ & $51.0 \pm 0.0 \mathrm{~b}$ & $2.0 \pm 0.6 \mathrm{~b}$ \\
Bima 7 & $49.0 \pm 0.0$ & $51.0 \pm 0.0 \mathrm{~b}$ & $2.0 \pm 0.0$ \\
Lamuru & $48.0 \pm 1.7$ & $50.0 \pm 1.7$ & $1.3 \pm 0.6$ \\
\hline NP t-Dunnet $\alpha 0.05$ & $46.7 \pm 0.6$ & $47.3 \pm 1.2$ & 0.7 \\
\hline
\end{tabular}

Keterangan: Angka yang diikuti oleh huruf kecil pada kolom yang sama berarti a : berarti berbeda nyata dengan var. Bima 7; $b$ : berbeda nyata dengan var. Lamuru berdasarkan Uji t-Dunnet $\alpha 0.05 ; \pm \mathrm{SD} ; \mathrm{ns}$ : tidak berbeda nyata dengan kedua varietas pembanding 
Peubah ASI menunjukkan selisih antara munculnya bunga jantan dan bunga betina. Hasil pengamatan menunjukkan bahwa selisih antara keluarnya bunga jantan dan betina berada dalam kisaran optimal yaitu antara 1.32 hari (Tabel 2). Hal ini sesuai dengan yang dikemukakan oleh Subekti et al. (2010) bahwa bunga jantan muncul 1-3 hari sebelum munculnya bunga betina. Kondisi ini memungkinkan terjadinya sinkronisasi dalam proses penyerbukan dan pembuahan sehingga berpotensi untuk menghasilkan produksi maksimal.

\section{Tinggi Letak Tongkol dan Umur Panen}

Genotipe tidak memberikan pengaruh yang nyata terhadap tinggi letak tongkol. Umur panen dari beberapa genotipe yang diuji memperlihatkan adanya perbedaan yang nyata, namun demikian rata-rata umur panen dari genotipegenotipe yang diuji berada antara 85-87 hari sehingga semua genotipe layak dikembangkan sebagai varietas berumur genjah (Tabel 3).

Umur tanaman berhubungan dengan faktor genetik tanaman, itulah sebabnya tiap galur atau varietas yang diuji memiliki umur tanaman yang berbeda. Hal ini sesuai yang dikemukakan oleh Masdar et al. (2006), bahwa tanaman akan memperlihatkan matang panen jika total energi yang diadopsi sudah mencapai batas taraf tertentu (growing degree day) dan batas taraf tertentu berbeda-beda pada masing-masing tanaman yang disebabkan oleh faktor genetik. Hasil pengamatan umur berbunga (Tabel 2) dan umur panen (Tabel 3) menunjukkan bahwa genotipe GJ5 memiliki waktu keluarnya bunga betina yang lebih cepat (47.7 hari) dan umur panen yang lebih cepat (85.7 hari) dibandingkan varietas Lamuru. Menurut Umar (2008), umur $50 \%$ berbunga berkorelasi positif dengan umur tanaman atau masa panen, artinya galur/varietas yang mempunyai umur $50 \%$ berbunga lebih pendek, maka umur masak galur/varietas tersebut juga lebih pendek, atau biasa disebut dengan berumur genjah.

\section{Komponen Hasil}

Bobot tongkol dipengaruhi oleh perbedaan genotipe, demikian pula bobot tongkol per petak dan bobot biji kering (kadar air 15\%) per ha (Tabel 4). Peubah bobot tongkol pada Genotipe GJ6 memiliki bobot tongkol yang nyata lebih berat (226.33 g) dibandingkan dengan varietas Lamuru, kemudian diikuti dengan GJ8 dengan bobot 220.27 g tetapi tidak berbeda nyata dengan kedua varietas pembanding yang digunakan. Peubah bobot tongkol per petak menunjukkan bahwa bobot tongkol per petak terberat diperoleh pada genotipe GJ8 dengan bobot yang dihasilkan sebesar 9.44 kg per petak dan nyata lebih berat dibandingkan dengan kedua varietas pembanding yang digunakan (Bima 7 dan Lamuru) yang hanya menghasilkan tongkol masing-masing $7.66 \mathrm{~kg}$ dan $6.38 \mathrm{~kg}$ per petak. Demikian pula pada peubah bobot biji kering per ha menunjukkan bahwa genotipe GJ8 menghasilkan bobot biji kering yang tertinggi yaitu 8.31 ton $\mathrm{ha}^{-1}$ dan nyata lebih tinggi dibandingkan dengan produksi biji kering varietas Bima 7 dan Lamuru yang hanya menghasilkan 6.95 ton ha ${ }^{-1}$ dan 5.74 ton ha ${ }^{-1}$, kemudian diikuti oleh genotipe GJ6 dengan tingkat produksi 6.85 ton $\mathrm{ha}^{-1}$ dan selanjutnya genotipe GJ7 dengan tingkat produksi 6.51 ton $\mathrm{ha}^{-1}$. Hal ini berarti bahwa ketiga genotipe ini berpotensi untuk dikembangkan sebagai varietas hibrida umur genjah yang berproduksi tinggi. Jagung hibrida yang diharapkan yaitu memiliki umur genjah dengan hasil yang tinggi. Pengembangan jagung umur genjah dan produksi tinggi sangat penting artinya bagi petani dalam menghadapi perubahan iklim global serta akan memperluas areal penanaman jagung, sehingga mendukung program peningkatan produksi jagung nasional.

Tabel 3. Tinggi letak tongkol (cm) dan umur panen (Hari) dari berbagai genotipe jagung calon hibrida umur genjah

\begin{tabular}{lcc}
\hline Genotipe jagung & Tinggi letak tongkol $(\mathrm{cm})$ & Umur panen (hari) \\
\hline GJ1 & $129.13 \pm 16.31$ & $86.3 \pm 1.2 \mathrm{~ns}$ \\
GJ2 & $111.67 \pm 10.21$ & $85.0 \pm 0.0 \mathrm{~ns}$ \\
GJ3 & $119.53 \pm 8.21$ & $85.0 \pm 0.0 \mathrm{~ns}$ \\
GJ4 & $118.67 \pm 5.69$ & $87.0 \pm 0.0 \mathrm{a}$ \\
GJ5 & $107.40 \pm 2.36$ & $85.7 \pm 1.2 \mathrm{~ns}$ \\
GJ6 & $147.73 \pm 10.53$ & $85.0 \pm 0.0 \mathrm{~ns}$ \\
GJ7 & $139.13 \pm 3.20$ & $85.7 \pm 1.2 \mathrm{~ns}$ \\
GJ8 & $141.93 \pm 10.63$ & $86.3 \pm 1.2 \mathrm{~ns}$ \\
Bima 7 & $149.33 \pm 3.41$ & $85.0 \pm 1.2$ \\
Lamuru & $114.93 \pm 7.14$ & $86.3 \pm 0.0$ \\
\hline NP t-Dunnet $\alpha 0.05$ & $\mathrm{~ns}$ & 1.4 \\
\hline
\end{tabular}

Keterangan: Angka yang diikuti oleh huruf kecil pada kolom yang sama: a berarti berbeda nyata dengan var. Bima 7; b : berarti berbeda nyata dengan var. Lamuru berdasarkan Uji t-Dunnet $\alpha 0.05 ; \pm \mathrm{SD} ; \mathrm{ns}$ : tidak berbeda nyata dengan kedua varietas pembanding 
Tabel 4. Bobot per tongkol, bobot tongkol per petak, dan bobot biji kering per ha

\begin{tabular}{lccc}
\hline Genotipe jagung & Bobot per tongkol $(\mathrm{g})$ & Bobot tongkol (kg per petak) & Bobot biji kering (ton ha- $)^{-1}$ \\
\hline GJ1 & $199.53 \pm 19.19 \mathrm{~ns}$ & $7.33 \pm 1.71 \mathrm{~ns}$ & $6.41 \pm 1.46 \mathrm{~ns}$ \\
GJ2 & $213.47 \pm 21.41 \mathrm{~ns}$ & $6.68 \pm 1.24 \mathrm{~ns}$ & $6.00 \pm 1.17 \mathrm{~ns}$ \\
GJ3 & $188.13 \pm 13.79 \mathrm{~b}$ & $6.33 \pm 0.82 \mathrm{~ns}$ & $5.61 \pm 0.71 \mathrm{~ns}$ \\
GJ4 & $191.8 \pm 14.51 \mathrm{~b}$ & $7.05 \pm 0.51 \mathrm{~ns}$ & $6.26 \pm 0.65 \mathrm{~ns}$ \\
GJ5 & $209.73 \pm 21.41 \mathrm{~ns}$ & $6.43 \pm 1.24 \mathrm{~ns}$ & $5.83 \pm 1.09 \mathrm{~ns}$ \\
GJ6 & $226.33 \pm 25.57 \mathrm{a}$ & $7.55 \pm 0.57 \mathrm{~ns}$ & $6.85 \pm 0.65 \mathrm{~ns}$ \\
GJ7 & $201.87 \pm 20.22 \mathrm{~ns}$ & $7.33 \pm 0.18 \mathrm{~ns}$ & $6.51 \pm 0.15 \mathrm{~ns}$ \\
GJ8 & $220.27 \pm 22.61 \mathrm{~ns}$ & $9.44 \pm 1.34 \mathrm{ab}$ & $8.31 \pm 1.08 \mathrm{ab}$ \\
Bima 7 & $199.13 \pm 9.76$ & $7.66 \pm 1.00$ & $6.95 \pm 1.00$ \\
Lamuru & $219.47 \pm 0.00$ & $6.38 \pm 0.00$ & $5.74 \pm 0.60$ \\
\hline NP t-Dunnet $\alpha 0.05$ & 27.07 & 1.61 & 1.34 \\
\hline
\end{tabular}

Keterangan: Angka yang diikuti oleh huruf kecil pada kolom yang sama: a berarti berbeda nyata dengan var. Bima 7; b berarti berbeda nyata dengan var. Lamuru berdasarkan pada Uji t-Dunnet $\alpha 0.05 ; \pm \mathrm{SD}$, ns : tidak berbeda nyata dengan kedua varietas pembanding

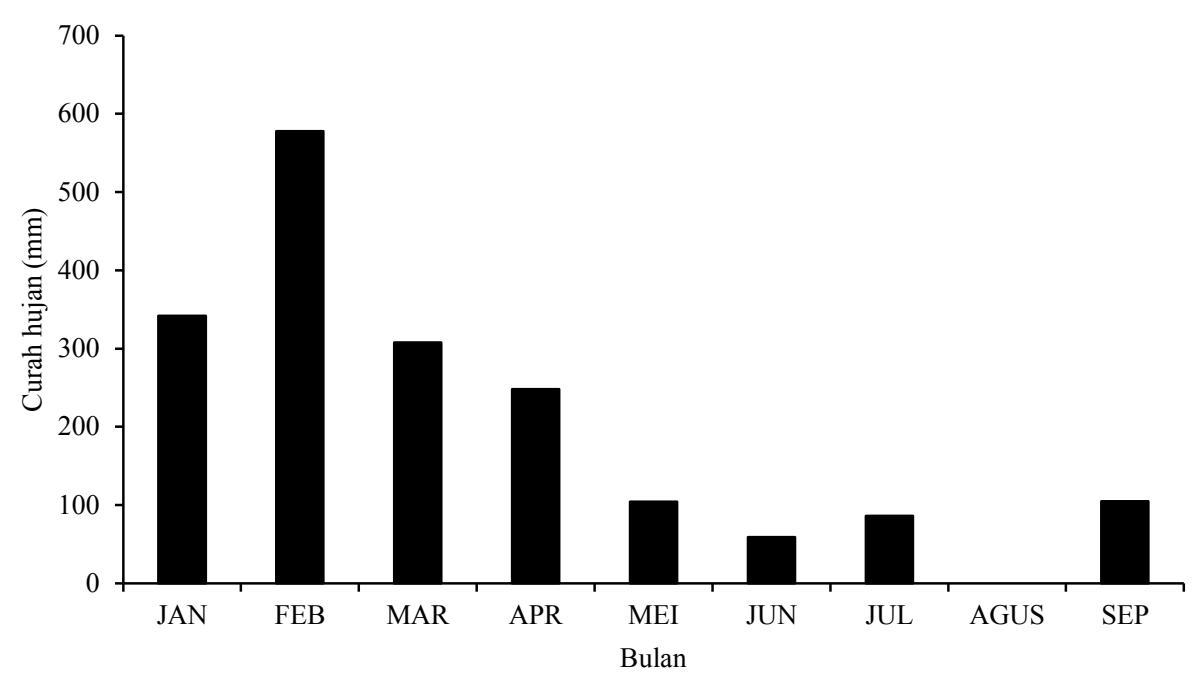

Gambar 1. Distribusi Curah Hujan Bulanan dari Bulan Januari-September 2016 di Lokasi Penelitian

\section{KESIMPULAN}

Genotipe GJ1, GJ6, GJ7 dan GJ8 memperlihatkan pertumbuhan tanaman yang lebih tinggi dibandingkan dengan Bima 7 dan Lamuru. Genotipe-genotipe yang diuji mempunyai umur panen kurang lebih 90 hari. Genotipe GJ6, GJ7 dan GJ8 berturut-turut menghasilkan 6.85, 6.51, dan 8.31 ton ha $^{-1}$, yang lebih tinggi dibandingkan dengan Bima 7 dan Lamuru. Perlu penelitian lanjutan pada ketiga genotipe pada kondisi riil di lapangan sebelum dikembangkan sebagai varietas hibrida jagung umur genjah dan berproduksi tinggi.

\section{UCAPAN TERIMA KASIH}

Ucapan terima kasih disampaikan kepada KEMENRISTEK DIKTI yang telah memberikan bantuan biaya melalui Skim Penelitian Unggulan Perguruan Tinggi TA. 2016-2017 dan juga ucapan terima kasih disampaikan kepada BALITSEREAL yang telah memberikan materi genetik untuk diuji sehingga penelitian ini bisa berjalan.

\section{DAFTAR PUSTAKA}

Azrai, M. 2013. Jagung hibrida genjah: prospek pengembangan menghadapi perubahan iklim. Iptek Tanaman Pangan 8:90-96.

Ali, F., I.A. Shah, M. Noor, M.Y. Khan, I. Ullah. 2012. Heterosis for yield and agronomic attributes in diverse maize germplasm. Austr. J. Crop Sci. 6:455460. 
Balai Penelitian dan Pengembangan Pertanian. 2011. Pedoman Umum Adaptasi Perubahan Iklim Sektor Pertanian. Badan Penelitian dan Pengembangan Pertanian, Kementerian Pertanian, Jakarta, Indonesia.

Bello, O.B., S.Y. Abdulmaliq, S.A. Ige, J. Mahamood, F. Oluleye, M.A. Azeez, MS. Afolabi. 2012. Evaluation of early and late/intermediate maize varieties for grain yield potential and adaptation to a Southern Guinea Savanna agro-ecology of Nigeria. Internat. J. Plant Res. 2:14-21.

Biro Pusat Statistika. 2016. Statistik Indonesia. www. bps. go. id. [12 Maret 2016].

Chaves, M.M., J. Flexas, C. Pinheiro. 2009. Photosynthesis under drought and salt stress: regulation mechanisms from whole plant to cell. Ann. Bot. 103:551-560.

Epeoglu, B., Y. Ekmekci, N. Cicek. 2009. Physiological responses of three maize cultivars to drought stress and recovery. South African J. Bot. 75:34-42.

Firdaus, K., Arifuddin, H.G. Yasin. 2002. Metode pendugaan hasil jagung. Pusat Penelitian dan Pengembangan Tanaman Pangan. BALITSEREAL, Maros. INA.

Garba, L.L., O.A.T. Namo. 2013. Productivity of maize hybrid maturity classes in savanna agro-ecologies in Nigeria. African Crop Sci. J. 21:323-335.

Iriany, N.R., S. Sujiprihati, M. Syukur, J. Koswara, M. Yunus. 2011. Evaluasi daya gabung dan heterosis lima galur jagung manis (Zea mays var. saccharata) hasil persilangan dialel. J. Agron. Indonesia 39:103111.

Kementerian Pertanian. 2014. Statistik Lahan Pertanian Tahun 2009-2013. Informasi Pertanian, Sekertariat Jenderal-Kementerian Pertanian. Jakarta, Indonesia.

Masdar, M. Karim, B. Rusman, N. Hakim, Helmi. 2006. Tingkat hasil dan komponen hasil sistem intensifikasi padi (SRI) tanpa pupuk organik di daerah curah hujan tinggi. JIPI. 8:126-131.

Prabowo, A., S.S. Arif, L. Sutiarso, B. Purwantana. 2014. Model simulasi pengembangan sistem irigasi untuk tanaman jagung di lahan sawah dan lahan kering (Studi kasus pada usahatani Jagung di Kabupaten Kediri). J. Agritech. 34:203-214.

PusatPenelitiandanPengenbanganPertanian(Puslitbangtan). 2007. Padi dan jagung hibrida unggul baru. Warta 19:2-3.

Putra, R.Y., Anggia E.P., D. Ruswandi. 2008. Daya gabung umum galur-galur jagung manis di Jawa Barat. Zuriat 19:210-217.

Subaedah, St., A.Takdir, Netty, Hidrawati. 2016. Evaluation of potential production of maize genotypes of early maturity in rainfed lowland. Internat. J. Biol. Agric. Food Biotechnol. Engineering 10:585-587.

Subaedah, St., Nirwana, Suriyanti. 2014. Improvement of yield maize in dry land who experience drought stress with use of organic matter. Adv. Environ. Biol. 8:930-934.

Subekti, N.A., Syafruddin, R. Efendi dan S.Sunarti. 2010. Morfologi tanaman dan fase pertumbuhan jagung. Dalam Teknik Produksi dan Pengembangan. P. 1628. Balitsereal, Maros.

Suwarno, P.M., D. Wirnas, A. Junaedi. 2016. Kendali genetik toleransi kekeringan pada padi sawah (Oryza sativa L.). J. Agron. Indonesia 44:119-125.

Umar, S. 2008. Variasi genetic, heritabilitas. dan korelasi genotipik sifat-sifat penting tanaman wijen (Sesamum indicum L.). J. Littri 13:88-92.

Utomo, S. 2012. Dampak impor dan ekspor jagung terhadap produktivitas jagung di Indonesia. J. Etikonomi 11:158-179. 